\title{
WHO ARE THE MOST UNEMPLOYED PEOPLE IN NEW ZEALAND AND WHAT CAN WE DO ABOUT IT?
}

\author{
Pauline B. Guerin \\ Elsie Ho \\ Richard Bedford
}

Migration Research Group
University of Waikato

\begin{abstract}
This paper presents an analysis of data for the top ten most unemployed groups by ethnicity and birthplace who were living in New Zealand at the 2001 Census. These groups are either from refugee backgrounds, are highly visible groups, or come from strong extended family networks. These data are supplemented with information from the New Zealand Immigration Service's Longitudinal Immigration Pilot Survey and Refugee Voices Project as well as qualitative data from other research in New Zealand. Overall, the findings from this assessment of the census and survey data have significant implications for the development and provision of employment intervention programmes in New Zealand.
\end{abstract}

\section{Introduction}

With the release of the New Zealand Immigration Service's Longitudinal Immigration Survey: New Zealand (LisNZ) Pilot Survey report in March 2004 and the Refugee Voices report in June 2004, there has been increased attention on the issues of employment (or unemployment) among migrants and refugees in New Zealand. Briefly, LisNZ Pilot Survey interviewed more than 500 migrants six months after residency in New Zealand (Wave 1) and again one year later (Wave 2). Refugee Voices interviewed a total of 398 refugees who were categorised as either recently arrived (interviewed at six months post-arrival and again at two years) or established refugees (i.e., those who had been in New Zealand for about five years).

LisNZ showed that, overall, the employment rate of participants increased from $53 \%$ to $62 \%$ and the labour force activity rate increased from $63 \%$ to $66 \%$ from Wave 1 to Wave 2 and the seeking work rate (i.e., unemployment rate) fell from $14 \%$ to only $6 \%$. Some factors they found associated with higher employment rates were having English as the language they spoke best, being younger (25-34), having worked in New Zealand before their residency was approved, having higher qualifications and being from Europe, South Africa or North America (ESANA; rather than from North Asia).

Similarly, Refugee Voices found that recently arrived refugees, who had been in New Zealand for only six months, had a labour force participation rate of $26 \%$ and $38 \%$ of them were 'seeking work' (i.e., unemployed). Labour force activity improved for these refugees when they were interviewed again after being in New Zealand for two years (i.e., their labour force participation rate increased to $33 \%$ and only $22 \%$ of them were 'seeking work'). These figures were related somewhat to the region of origin that the refugees were from, with higher labour force participation rates and lower seeking work rates among South Asian refugees compared with those from the Middle East (or Southwest Asia), Horn of Africa or South East Asia'. Refugees who had been in New Zealand for five years or more did not show much change as their labour force participation rate was still only $38 \%$ and $23 \%$ of them were 'seeking work'. Region of origin comparisons showed the highest seeking work rates among those from the Middle East and the Horn of Africa.

Both Refugee Voices and LisNZ have provided valuable information relating to the settlement of refugees and migrants in New Zealand, but both reports included information from relatively small sample sizes and the data are not compared with (or necessarily comparable with) data about other immigrant and refugee groups that can be identified, for example, in the New Zealand Census of Population and Dwellings.

Boyd (2003) analysed 1996 and 2001 Census data for migrant groups in New Zealand and found that overall employment of migrant groups was improving (46\% to $50.4 \%$ from 1996 to 2001$)$ and unemployment was decreasing, $(11.7 \%$ to $8.4 \%)$. However, there was still evidence of discrimination in the labour market against migrants from some areas in spite of their higher qualifications. While employment rates were lower for migrants from non-English speaking countries, Boyd also found that these unemployment rates persisted even after living in New Zealand for more than 10 years. Boyd also found increases in proportions of recent migrants not in the labour force, especially among those from North and South East Asia and the Pacific.

There are some limitations of these reports that make identification of the key factors influencing participation in paid employment difficult to determine. For example, 
there is huge cultural, linguistic and ethnic diversity among migrants from South, North, or South East Asia. This diversity cannot be teased out from these reports. Despite the greater detail given about migrant groups in the reports, somewhat ironically, there is still an invisibility of the most 'visible' migrants in New Zealand, such as black Africans and Muslim women. We sought to further investigate statistics from the 2001 Census by taking a more disaggregated approach to the birthplace and ethnic groups that are identified in the published statistics. We investigated the top 10 most unemployed groups in New Zealand by birthplace and ethnicity in terms of their education attainment, languages spoken and labour force participation, and coupled this with some more general information about their countries of origin as a way of understanding better some of the factors influencing their employment in New Zealand.

Table 1 depicts the top 10 most unemployed groups in New Zealand by 'Birthplace' and by 'Ethnicity', as well as the employment rates (ER), labour force participation rates (LFPR) and the proportion not in the labour force (NoLF). The groups are listed in terms of unemployement rates - from highest to lowest. In this paper, unemployment rate (UR) refers to the proportion of those aged 15 years and over who were looking for work out of all those in the labour force. Employment rate (ER) is the proportion of people in a group who are working fulltime or part-time out of the total for that group. Labour force participation rate (LFPR) is the proportion of those who are working or looking for work; and non-labour force participation rate (NoLF) is the proportion of those who are not participating in the labour force. The proportion of those who did not state their labour force status in the census questionnaire is not shown in Table 1.

In 2001, people born in Afghanistan, Somalia, Kuwait, Bangladesh and Iraq had unemployment rates four to five times higher than the national average of $7.5 \%$ (Table 1 ). The next five most unemployed birthplace groups (i.e. Taiwan. Tokelau, Iran, Egypt and Tuvalu) also had high uncmployment rates ranging from 19 to $24 \%$.

Among the top 10 most unemployed birthplace groups, the Taiwan-born had the lowest employment rate $(23 \%)$ and the lowest labour force participation rate $(30 \%)$, followed by people born in Afghanistan (24\% and $39 \%$ ), Somalia $(25 \%$ and $39 \%)$ and Kuwait $(29 \%$ and $46 \%)$. Table 1 also gives the top 10 most unemployed groups in New Zealand by ethnicity. The 2001 census found that: the ethnic group with the highest unemployment rates were Assyrians (40\%), Somalis (37\%), Iraqis (31\%) and Bangladeshis $(31 \%)$ and the ethnic group with the lowest cmployment rate $(24 \%)$ and the lowest level of labour force participation $(32 \%)$ were the Taiwanese Chinese.

Three main characteristics emerge about these most unemployed groups in New Zealand. First, most of the unemployed groups in New Zealand come from refugee backgrounds. Second, many of those in these groups are highly visible, making them targets for discrimination and racism both in their everyday lives as well as in their search for employment. Finally, many of these groups are non-westernized with strong extended family systems that are do not fit easily with the prevailing norms in a highly western-based, nuclear-family oriented welfare state.

Table 1 shows that the majority of the most unemployed groups in New Zealand come from refugee backgrounds. According to the United Nations High Commissioner for Refugees (2004), the top 10 countries of origin for refugees were Afghanistan, Sudan, Burundi, the Democratic Republic of Congo, Palestinians, Somalia, Iraq, Viet Nam, Liberia and Angola. Of these, Afghanistan, Somalia, and Iraq feature in Table 1. Additionally, Pakistan, Iran, Iraq, and Egypt are major countries of asylum for refugees so that some who were born in these countries may have been refugees.

It is not possible to determine the number of refugees and asylum seekers within each of the groups identified in Table 1 because information on residency status is not collected in the census questionnaire. Also, some who have refugee backgrounds may come to New Zealand on other visa routes, not necessarily as refugees or asylum seekers. However, the total number of quota refugees accepted into New Zealand from the above groups from 1979-2001 include Afghans (115), Somalis (1437), Kuwaiti (11), Iraqi (1899), and Iranian (404; NZIS, 2004). Most of these groups are also represented in approved asylum seeker applications and would likely have had family arriving through the regular family reunification channel in the New Zealand immigration programme.

The findings about the Taiwanese Chinese are surprising. The common perception of the Taiwanese Chinese is that they are 'quality migrants' with high professional qualifications and business entrepreneurship. So, what does this group of talented professional migrants have in common with the nation's most disadvantaged refugee groups? In the next section, we further analyse census data relating to the top 10 most unemployed groups in an attempt to understand some of the other social properties of these unemployment rates.

\section{Language Abilities, Qualifications and Unemployment}

Table 2 depicts the proportion of these birthplace and ethnic groups speaking English or no English, and the proportion of ethnic groups speaking two or more languages. In 2001, one in three Afghanistan-born, one in four Somalia-born and one in six Tuvalu-born indicated that they could not conduct an everyday conversation in English. While it is perhaps not surprising that a few of the ethnic groups with the highest unemployment rates also have high proportions who do not speak English, what is surprising is the high proportion who speak two or more languages. Among the 10 most unemployed ethnic groups in New Zealand, seven (i.e. Taiwanese Chinese, Arab, Iraqi, Assyrian, Pakistani, Iranian and Bangladeshi) have at least $65 \%$ of their group who speak two or more languages. In addition, eight out of these 10 groups have $80 \%$ or more of their group who do speak English, including the Taiwanese Chinese $(86 \%$ speak English), suggesting that English ability, by itself, does not necessarily translate into getting a job. 
Table 1: Labour Force Status Rates for Men and Women, Aged 15 Years and Over, of the Top 10 Most Unemployed Groups in New Zealand by Birthplace and Ethnicity, in the 2001 Census

\begin{tabular}{|c|c|c|c|c|c|c|c|c|c|}
\hline Birthplace (n) & UR & ER & LFPR & NoLF & Ethnicity (n) & UR & ER & LFPR & NoLF \\
\hline $\begin{array}{l}\text { Afghanistan } \\
(528)\end{array}$ & 38.2 & 23.9 & 38.6 & 61.4 & $\begin{array}{l}\text { Assyrian } \\
(861)\end{array}$ & 40.0 & 25.1 & 41.8 & 58.2 \\
\hline Male & 41.2 & 29.7 & 50.5 & 49.5 & Male & 40.8 & 30.9 & 51.1 & 48.2 \\
\hline Female & 35.3 & 14.5 & 22.7 & 76.3 & Female & 37.5 & 20.4 & 32.7 & 67.3 \\
\hline $\begin{array}{l}\text { Somalia } \\
(1206)\end{array}$ & 37.3 & 24.6 & 39.4 & 60.4 & $\begin{array}{l}\text { Somali } \\
(1128)\end{array}$ & 37.2 & 24.7 & 39.4 & 60.6 \\
\hline Male & 35.0 & 32.7 & 50.2 & 49.8 & Male & 34.0 & 34.7 & 51.8 & 48.2 \\
\hline Female & 42.6 & 15.8 & 27.6 & 72.4 & Female & 42.9 & 14.8 & 26.9 & 74.2 \\
\hline $\begin{array}{l}\text { Kuwait } \\
(318)\end{array}$ & 36.7 & 29.2 & 45.8 & 54.7 & $\begin{array}{l}\text { Iraqi } \\
(1515)\end{array}$ & 31.2 & 35.8 & 52.1 & 47.9 \\
\hline Male & 36.4 & 36.1 & 55.0 & 44.3 & Male & 28.7 & 43.3 & 60.7 & 39.3 \\
\hline Female & 40.0 & 22.2 & 34.1 & 64.4 & Female & 35.4 & 27.2 & 42.1 & 57.4 \\
\hline $\begin{array}{l}\text { Bangladesh } \\
(939)\end{array}$ & 29.4 & 40.9 & 57.5 & 42.5 & $\begin{array}{l}\text { Bangladeshi } \\
(789)\end{array}$ & 30.9 & 39.5 & 56.7 & 43.0 \\
\hline Male & 26.2 & 50.3 & 67.8 & 32.0 & Male & 28.0 & 48.7 & 66.7 & 32.7 \\
\hline Female & 36.2 & 27.3 & 43.6 & 56.8 & Female & 38.8 & 27.4 & 43.4 & 56.6 \\
\hline $\begin{array}{l}\text { Iraq } \\
(3810)\end{array}$ & 28.7 & 37.9 & 53.1 & 46.9 & $\begin{array}{l}\text { Arab } \\
(1938)\end{array}$ & 27.5 & 40.7 & 56.2 & 44.0 \\
\hline Male & 26.9 & 45.9 & 63.0 & 37.0 & Male & 26.6 & 49.0 & 66.8 & 33.2 \\
\hline Female & 31.7 & 37.9 & 42.5 & 57.5 & Female & 29.2 & 31.3 & 43.8 & 56.2 \\
\hline Taiwan & & & & & Rarotongan & & & & \\
\hline$(10482)$ & 23.6 & 22.8 & 29.9 & 70.1 & $(567)$ & 24.4 & 52.4 & 69.3 & 31.2 \\
\hline Male & 24.0 & 25.5 & 33.5 & 66.5 & Male & 24.3 & 58.1 & 75.3 & 24.7 \\
\hline Female & 23.1 & 20.8 & 27.0 & 73.0 & Female & 25.0 & 46.9 & 62.5 & 37.5 \\
\hline $\begin{array}{l}\text { Tokelau } \\
\text { (1494) }\end{array}$ & 22.7 & 43.8 & 56.7 & 43.2 & $\begin{array}{l}\text { Taiwanese/Chinese } \\
(3129)\end{array}$ & 23.1 & 24.3 & 31.5 & 68.6 \\
\hline Male & 19.5 & 51.5 & 64.2 & 35.7 & Male & 24.0 & 26.4 & 35.0 & 65.2 \\
\hline Female & 26.4 & 36.6 & 50.0 & 50.2 & Female & 22.8 & 22.3 & 28.7 & 71.3 \\
\hline $\begin{array}{l}\text { Iran } \\
(1725)\end{array}$ & 22.4 & 46.4 & 59.9 & 40.0 & $\begin{array}{l}\text { Tokelauan } \\
(3567)\end{array}$ & 22.4 & 48.8 & 62.8 & 37.2 \\
\hline Male & 22.0 & 52.1 & 66.4 & 33.6 & Male & 19.5 & 48.8 & 70.4 & 29.6 \\
\hline Female & 23.1 & 38.9 & 50.8 & 49.0 & Female & 25.6 & 41.7 & 55.9 & 44.0 \\
\hline $\begin{array}{l}\text { Egypt } \\
(969)\end{array}$ & 19.8 & 44.9 & 56.3 & 43.7 & Iranian/Persian ( I 668) & 22.3 & 46.8 & 60.4 & 39.7 \\
\hline Male & 18.6 & 53.7 & 65.9 & 34.5 & Male & 21.8 & 52.2 & 66.7 & 33.3 \\
\hline Female & 23.4 & 34.2 & 44.1 & 55.5 & Female & 23.3 & 39.7 & 51.7 & 48.7 \\
\hline Tuvalu & & & & & Pakistani & & & & \\
\hline (786) & 18.5 & 50.0 & 61.6 & 38.5 & $(714)$ & 19.3 & 49,2 & 60.9 & 39.1 \\
\hline Male & 15.1 & 60.8 & 72.3 & 27.5 & Male & 17.6 & 59.7 & 72.5 & 28.2 \\
\hline Female & 22.7 & 40.6 & 52.4 & 47.6 & Female & 27.0 & 30.7 & 42.0 & 58.0 \\
\hline NZ born & 7.1 & 64.1 & 69.0 & 31.0 & NZ European & 5.5 & 64.3 & 68.1 & 31.9 \\
\hline Male & 6.6 & 71.2 & 76.2 & 23.8 & Male & 5.2 & 71.5 & 75.4 & 24.6 \\
\hline Female & 7.6 & 57.6 & 62.3 & 37.7 & Female & 5.9 & 57.8 & 61.4 & 38.6 \\
\hline Total NZ & 7.5 & 59.8 & 66.7 & 32.3 & & & & & \\
\hline Male & 7.0 & 66.5 & 73.8 & 25.4 & & & & & \\
\hline Female & 8.0 & 53.8 & 60.1 & 38.7 & & & & & \\
\hline
\end{tabular}

Source: Statistics New Zealand (2002a, Table 16;2002b, Table 17a) 
Table 3 shows the highest educational qualifications attained and similarly shows, not surprisingly, high proportions with no qualifications among some of these most unemployed groups. Four out of these 10 birthplace groups (i.e. Tokelau, Tuvalu, Somalia and Afghanistan) had a majority of their group having no or school only qualifications, especially among women. However, there is also a high proportion in many of these groups with degree qualifications and a very low proportion with no qualification (e.g. Bangladesh, Egypt, Iraq, Iran, Kuwait and Taiwan), especially compared with the NZ Total and NZ born. Similarly, Boyd (2004) found $24 \%$ of recent migrants $(0-5$ years $)$ had university qualifications compared with only $10 \%$ of those born in New Zealand.

Table 2: Top 10 Most Unemployed Groups in NZ by Birthplace and Ethnicity, Proportion of Men and Women Speaking No English, English and Speaking Two or More Languages, 2001

\begin{tabular}{|c|c|c|c|c|c|c|}
\hline Birthplace & No English & English & Ethnicity & No English & English & $\begin{array}{l}\text { Two or more } \\
\text { languages }\end{array}$ \\
\hline Afghanistan & 33.3 & 62.6 & Assyrian & 30.1 & 67.0 & 75.8 \\
\hline Male & 24.5 & 71.9 & Male & 26.2 & 70.2 & 76.8 \\
\hline Female & 44.3 & 50.9 & Female & 34.0 & 63.9 & 75.1 \\
\hline Somalia & 26.1 & 66.6 & Somali & 26.6 & 66.9 & 53.7 \\
\hline Male & 20.8 & 72.1 & Male & 21.4 & 72.3 & 56.3 \\
\hline Female & 31.9 & 61.0 & Female & 32.2 & 61.4 & 50.3 \\
\hline Tuvalu & 15.9 & 73.7 & Iraqi & 15.0 & 82.1 & 77.2 \\
\hline Male & 14.0 & 73.9 & Male & 11.7 & 85.6 & 78.6 \\
\hline Female & 17.6 & 74.2 & Female & 18.3 & 78.7 & 75.4 \\
\hline Iran & 15.5 & 82.1 & Iranian/Persian & 13.6 & 84.3 & 66.3 \\
\hline Male & 12.6 & 85.0 & Male & 11.8 & 86.0 & 67.2 \\
\hline Female & 19.4 & 78.5 & Female & 16.3 & 81.4 & 65.1 \\
\hline Iraq & 15.0 & 83.2 & Taiwanese/Chinese & 12.8 & 86.1 & 82.6 \\
\hline Male & 11.8 & 86.4 & Male & 11.4 & 87.5 & 83.5 \\
\hline Female & 18.4 & 79.7 & Female & 14.0 & 84.9 & 81.8 \\
\hline Taiwan & 13.0 & 84.0 & Bangladeshi & 11.3 & 84.2 & 64.8 \\
\hline Male & 11.0 & 86.3 & Male & 8.9 & 87.7 & 66.7 \\
\hline Female & 14.8 & 82.0 & Female & 14.7 & 80.0 & 64.2 \\
\hline Bangladesh & 11.9 & 84.8 & Pakistani & 10.8 & 84.9 & 67.8 \\
\hline Male & 9.0 & 88.7 & Male & 6.7 & 88.6 & 68.7 \\
\hline Female & 15.0 & 80.9 & Female & 15.9 & 79.5 & 67.4 \\
\hline Tokelau & 11.6 & 83.8 & Arab & 7.7 & 88.8 & 77.5 \\
\hline Male & 9.7 & 86.5 & Male & 7.3 & 89.0 & 77.0 \\
\hline Female & 13.2 & 81.5 & Female & 8.1 & 88.7 & 77.9 \\
\hline Kuwait & 8.6 & 90.8 & Tokelauan & 4.1 & 90.1 & 51.3 \\
\hline Male & 11.4 & 87.5 & Male & 3.5 & 91.2 & 49.3 \\
\hline Female & 4.7 & 93.8 & Female & 4.7 & 89.2 & 53.2 \\
\hline Egypt & 4.3 & 93.7 & Rarotongan & -- & 93.0 & 17.0 \\
\hline Male & 2.3 & 95.4 & Male & - & 90.5 & 16.2 \\
\hline Female & 6.9 & 92.0 & Female & -- & 95.0 & 17.7 \\
\hline NZ born & 0.5 & 96.1 & NZ European & 0.1 & 97.8 & 5.8 \\
\hline Male & 0.5 & 95.8 & Male & 0.1 & 97.6 & 5.2 \\
\hline Female & 0.5 & 96.4 & Female & 0.1 & 98.0 & 6.2 \\
\hline Total NZ & 1.7 & 91.7 & & & & \\
\hline Male & 1.6 & 91.5 & & & & \\
\hline Female & 1.8 & 91.8 & & & & \\
\hline
\end{tabular}

-- Percentages not given when numbers are less than 25.

Source: Statistics New Zealand (2002a, Tables 10 \& 11; 2002b, Tables 9a \& 10a) 
Table 3: Highest Educational Qualifications for Men and Women, Aged 15 Years and Over, of the Top 10 Most Unemployed Groups in New Zealand by Birthplace and Ethnicity, in the 2001 Census

\begin{tabular}{|c|c|c|c|c|c|c|c|c|c|}
\hline Birthplace & $\begin{array}{c}\text { No } \\
\text { qual. }\end{array}$ & School & Vocational & Degree & Ethnicity & $\begin{array}{c}\text { No } \\
\text { qual. }\end{array}$ & School & Vocational & Degree \\
\hline Tokelau & 37.3 & 26.9 & 10.6 & - & Rarotongan & 39.2 & 32.3 & 13.2 & - \\
\hline Male & 36.9 & 27.4 & 10.4 & - & Male & 41.5 & 29.8 & 8.5 & - \\
\hline Female & 37.7 & 26.5 & 10.9 & $\cdots$ & Female & 36.5 & 32.3 & 17.7 & - \\
\hline Tuvalu & 34.0 & 24.7 & 7.2 & -. & Tokelauan & 33.0 & 35.7 & 12.4 & 2.0 \\
\hline Male & 31.7 & 28.3 & 8.3 & -- & Male & 35.8 & 33.5 & 11.6 & 1.6 \\
\hline Female & 37.8 & 21.7 & 6.3 & - & Female & 30.4 & 37.6 & 13.0 & 2.6 \\
\hline Somalia & 30.7 & 28.2 & 6.0 & 3.5 & Assyrian & 32.4 & 42.5 & 4.5 & 4.9 \\
\hline Male & 25.4 & 33.2 & 7.8 & -- & Male & 30.7 & 40.0 & 3.6 & - \\
\hline Female & 36.2 & 22.4 & 4.6 & -- & Female & 34.0 & 38.1 & 4.8 & - \\
\hline Afghanistan & 21.0 & 39.8 & 5.1 & 8.5 & Somali & 31.0 & 26.9 & 5.9 & 3.5 \\
\hline Male & 17.0 & 43.0 & - & - & Male & 25.8 & 32.5 & 7.2 & 5.1 \\
\hline Female & 28.0 & 34.7 & - & - & Female & 36.6 & 22.4 & 4.4 & -. \\
\hline Iraq & 16.0 & 35.4 & 6.8 & 31.5 & Iraqi & 17.6 & 37.6 & 7.1 & 26.5 \\
\hline Male & 15.5 & 34.7 & 5.8 & 34.8 & Male & 17.0 & 35.9 & 7.0 & 29.6 \\
\hline Female & 16.7 & 36.2 & 8.0 & 28.0 & Female & 18.7 & 40.0 & 6.8 & 23.4 \\
\hline Iran & 7.3 & 49.4 & 12.0 & 20.5 & Iranian/Persian & 7.4 & 49.1 & 12.2 & 20.9 \\
\hline Male & 7.7 & 48.5 & 12.5 & 20.8 & Male & 7.4 & 48.6 & 12.7 & 21.4 \\
\hline Female & 7.1 & 50.8 & 11.3 & 20.2 & Female & 7.3 & 50.4 & 11.6 & 20.7 \\
\hline Kuwait & 6.6 & 54.7 & 9.4 & 19.8 & Pakistani & 5.9 & 36.3 & 8.0 & 38.8 \\
\hline Male & - & 59.0 & 9.8 & -. & Male & 5.3 & 31.3 & 8.7 & 41.3 \\
\hline Female & $-\cdot$ & 48.9 & 8.9 & - & Female & 5.7 & 40.9 & 6.8 & 33.0 \\
\hline Egypt & 5.0 & 35.3 & 9.0 & 43.3 & Arab & 5.0 & 35.9 & 8.0 & 44.7 \\
\hline Male & 4.5 & 33.1 & 7.3 & 47.8 & Male & 5.2 & 35.5 & 7.2 & 46.1 \\
\hline Female & 5.5 & 38.4 & 11.0 & 37.7 & Female & 5.0 & 36.9 & 9.1 & 43.0 \\
\hline Taiwan & 4.5 & 65.1 & 7.2 & 16.9 & Taiwanese/Chinese & 5.0 & 65.9 & 7.3 & 14.6 \\
\hline Male & 4.4 & 66.6 & 6.0 & 16.9 & Male & 5.6 & 65.7 & 6.1 & 15.5 \\
\hline Female & 4.5 & 63.9 & 8.2 & 17.0 & Female & 4.4 & 65.9 & 8.3 & 13.8 \\
\hline Bangladesh & 4.2 & 29.4 & 4.8 & 55.3 & Bangladeshi & 4.2 & 30.0 & 4.2 & 55.5 \\
\hline Male & - & 26.5 & - & 58.6 & Male & 3.4 & 26.8 & 4.0 & 60.4 \\
\hline Female & - & 33.3 & - & 50.0 & Female & 4.4 & 33.6 & 5.3 & 49.6 \\
\hline NZ born & 27.0 & 34.4 & 19.1 & 9.1 & NZ European & 24.6 & 35.5 & 20.0 & 10.2 \\
\hline Male & 27.8 & 32.7 & 19.8 & 9.5 & Male & 25.1 & 33.7 & 21.1 & 10.9 \\
\hline Female & 26.2 & 35.9 & 18.4 & 8.7 & Female & 24.1 & 37.1 & 18.9 & 9.5 \\
\hline Total NZ & 23.7 & 34.5 & 17.6 & 10.1 & & & & & \\
\hline Male & 24.3 & 32.9 & 18.3 & 10.7 & & & & & \\
\hline Female & 23.3 & 36.0 & 16.9 & 9.6 & & & & & \\
\hline
\end{tabular}

Source: Statistics New Zealand (2002a, Table 13; 2002b, Table 14a)

\section{Implications}

The data presented in this paper provide us with some interesting considerations in terms of intervention programmes in New Zealand for improving the employment status of certain migrant groups. For example, analysis of the top 10 most unemployed groups by ethnicity and birthplace revealed some interesting consistencies when cultural and economic backgrounds are considered. Data for language abilities and qualifications suggest that the issues with unemployment are more complex than just not speaking English wellenough or not having qualifications. Employment interventions for these groups cannot simply be based on western concepts and frameworks but need to consider the complexities of these migrants and their backgrounds.

Both LisNZ and Refugee Voices found that most migrants and refugees find their jobs through family and friends. Less important was language ability, skills or qualifications, and experience. On the other hand, 
difficulty with English and lack of New Zealand qualifications was seen as a big reason for having difficulty finding a job.

New Zealand is a primarily Christian country and most of the groups discussed in this paper are not Christian, but are Muslim, Buddhist or practice other religions. That most of these groups have religions that are very different to most New Zealanders suggests that either discrimination for religious reasons is an issue in New Zealand or that these religious differences make getting work in New Zealand more difficult. For example, Iran, Iraq, Kuwait, Bangladesh, Pakistan and Somalia are primarily Islamic countries. Most Muslim women practice the Islamic tradition of covering their hair with a head scarf which can make them highly visible and in a current world climate of hostility towards Muslims may disadvantage them in the labour market (Ahmed, 1999). More research is needed to tease out more specifically the importance of this issue (but see Guerin, Guerin, Diiriye \& Abdi, 2004, this conference).

Many of the countries of origin for the groups discussed in this paper are war-torn or developing countries and have had migration to New Zealand initiated by refugee programmes. However, our international humanitarian obligations in regards to refugees do not stop with simply providing residency in New Zealand. Indeed, issues with refugee employment are increasingly being acknowledged worldwide and, in New Zealand, the J. R. McKenzie Trust has been piloting interventions for dealing with refugee employment (2004). That project has found that individualised, sensitive approaches are essential when working with former refugees and that discrimination by employers and government department staff (such as in Work and Income New Zealand) is an issue in New Zealand. Other issues identified include lack of appropriate English or other educational programmes, and differences in workplace culture in New Zealand compared with their home countries.

Another possible consideration in the interpretation of these data is that most, if not all, of these groups come to New Zealand with both an expectation by the residents that they will become employed and also their own high hopes of employment in their new country. These contextual influences may result in an inflated rate of unemployment when, practically speaking, employment is not a viable option and their circumstances may be better categorized as 'not in the labour force' during a time of settlement. The persistent unemployment reported even after many years of living in New Zealand (Boyd 2004) may relate to a sort of snowball effect in which gaining employment becomes more and more difficult the longer one is out of the labour force.

An additional employment barrier faced by the Taiwanese Chinese is their seemingly lack of motivation to find a job, as reflected in their very low labour force participation rate and employment rate. Previous studies (sec, for example, Ho 2002; Ip 2003) reported that many of the high-skilled Taiwanese professionals were reluctant to seck employment in positions which were perecived to be lower than those they enjoyed in Taiwan.
Potential business entrepreneurs were reluctant to start a business in a market which is small, and where the perceived barriers of taxation and regulations are high. Consequently, many opt for early retirement, or adopt an 'astronaut' family arrangement where the wives stay in New Zealand to look after children and the husbands return to Taiwan to work. Some would have preferred to re-start their career or business in New Zealand if suitable intervention programmes had been available to help them overcome the labour market challenges in the new country.

Overall, it is important to consider that unemployment amongst these groups is not due to any shortcomings of the migrants themselves, but that there is a complex intertwining of multiple factors underpinning their employment experiences in New Zealand. Blaming these migrants as being somehow deficient shifts the responsibility of under- or un-employment onto the migrants themselves and is generally not helpful in addressing the problems. This is especially the case of refugees who have experienced or are currently experiencing a range of complex issues that influence successful resettlement.

\section{Conclusions}

This paper shows that more than education qualifications or language need to be considered in the development and provision of employment interventions for migrant groups in New Zealand. Overall, the diversity of key characteristics among those who have the highest unemployment rates in New Zealand suggests a corresponding diversity required in employment intervention programmes in New Zealand. For example, groups speaking multiple languages and with high education levels would benefit from very different intervention programmes compared with those who speak no English and have limited education backgrounds. The importance of social networking in obtaining employment in New Zealand also appears to be a major consideration in the development of interventions. Finally, and perhaps the most difficult to address, is the issue of discrimination in the labour market. This has not been addressed directly in this paper, but it is an issue we and others have addressed more directly in other places (Guerin et al. 2004; JR McKenzie Trust, 2004).

\section{Notes}

1. North Asia includes China, North and South Korea, Mongolia, Hong Kong, Japan, Macau, etc. South Asia includes Bangladesh, Bhutan, India, Sri Lanka, Maldives, Pakistan, Nepal, etc. South East Asia includes Brunei, Burma/Myanmar, Indonesia, Cambodia, Laos, Philippines, East Timor, Vietnam, Thailand, Malaysia, etc. The Middle East, or Southwest Asia, includes Iraq, Iran, and Afghanistan. The Horn of Africa includes Ethiopia, Somalia, Eritrea and Djibouti.

2. This work was supported by grants from the Foundation for Research, Science and Technology (UOWX0203, Strangers in Town: Enhancing Family 
and Community in a More Diverse New Zealand Society) and the University of Waikato.

\section{References}

Ahmed, S. (1999). Islam and development: Opportunities and constraints for Somali women. Gender and Development, 7, 69-72.

Boyd, C. (2003) Migrants in New Zealand: An Analysis of Labour Market Outcomes for Working Aged Migrants Using 1996 and 2001 Census Data. Wellington: Department of Labour.

Guerin, B., Guerin, P. B., Diiriye, R. O., Abdi, A. (2004). What skills do Somali refugees bring with them? Labour, Employment and Work in New Zealand Conference, Wellington.

Ho, E.S. (2002) Multi-local residence, transnational networks: Chinese 'astronaut' families in New Zealand. Asia and Pacific Migration Journal, 11(1): 145-164.

Ip, M. (2003) Seeking the last Utopia: the Taiwanese in New Zealand. In M. Ip (Ed) Unfolding History: Evolving Identity. The Chinese in New Zealand. Auckland: Auckland University Press, pp. 185210.
JR McKenzie Trust. (2004). Supporting refugee resettlement: Refugee Employment Programme: What have we learned so far? A report of the first two years of a three year programme. Accessed from www.jrmckenzie.org.nz 11 November 2004.

New Zealand Immigration Service. (2004a). Migrants' Experiences of New Zealand. Pilot Survey Report. Longitudinal Immigration Survey: New Zealand. Wellington: New Zealand Immigration Service, Department of Labour.

New Zealand Immigration Service. (2004b). Refugee Voices: A Journal Towards Resettlement. Wellington: Department of Labour.

Shih, J. (2002). '...Yeah, I could hire this one, but I know it's gonna be a problem': How race, nativity and gender affect employers' perceptions of the manageability of job seekers. Ethnic and Racial Studies, 25, 99-119.

Statistics New Zealand. (2002a). New Zealand Census of Population and Dwellings 2001: People Born Overseas.. Statistics New Zealand: Wellington. 